\title{
Comunicação e Consciência na Sociologia de Niklas Luhmann
}

\author{
Lidiane Rodrigues Domingues ${ }^{1}$
}

\section{Resumo}

A sociologia de Luhmann é polêmica nas Ciências Sociais por vários motivos, em primeiro lugar porque é uma teoria dos sistemas, ou seja, é generalizante; em segundo lugar por que sua epistemologia e alguns de seus princípios advêm de outras ciências, principalmente da física e da biologia. Quando Luhmann passou a lecionar na Universidade de Bielfeld em 1968 ele se comprometeu a construir uma nova teoria sociológica, uma teoria com a pretensão de definir um (novo) objeto da sociologia, o que de certo ele fez. Para Luhmann a sociologia deve observar apenas os sistemas comunicação sabendo que só o faz mediante comunicação, isto é, as ciências são sistemas de comunicação assim como a sociedade, como um todo, é considerada pelo autor como sistema de comunicação. A chamada teoria dos sistemas de Luhmann é generalizante, isto é, ao partir de um único ponto operativo observado na realidade (a comunicação!) sua teoria é capaz de definir o conceito preciso de sociedade, pois abarca, dentro dos seus limites epistemológicos, toda e qualquer comunicação e sociedade. Mais radical ainda é sua conclusão teórica de que a sociedade não é composta por pessoas, mas sim por linguagem no plano estrutural, e por seleção no plano operacional.

\footnotetext{
1 Universidade Federal de São Paulo; Escola de Filosofia, Letras e Ciências Humanas; Departamento de Ciências Sociais. Orientador: Prof. Doutor Mauro Luiz Rovai
} 
Para observar a contemporaneidade, a sociologia de Luhmann é extremamente interessante, porque observa as contingências, isto é, a dependência estrutural entre os mais diversos sistemas de comunicação do globo distinguindo-os operacionalmente, não por seus limites de fronteira. Sua teoria pode ser entendida como voltada para a realidade, que por ser extremamente complexa permite que sistemas se criem a partir de sistemas já existentes e constituintes desta realidade. O sistema de comunicação não existe como totalidade para um observador, nem para si mesmo, pelo contrário, trata-se de sistemas dentro de sistemas com funções variadas direcionadas por um único código operacional: aceitação e rejeição. Por exemplo, o sistema econômico é internacional, funciona mediante um meio simbolicamente generalizado: o dinheiro, que, segundo Luhmann, facilita a aceitabilidade desta comunicação em qualquer lugar a qualquer momento.

A epistemologia que permite a Luhmann definir a sociedade como sistema de comunicação é a Cibernética de Segunda Ordem aliada ao construtivismo, em sua teoria o conhecimento é criado por um observador através da observação de outro observador, ocorrendo sempre dentro deste paradoxo. Isso porque a Cibernética de Segunda Ordem ou a observação de segunda ordem tem como pressuposto o encerramento operacional dos sistemas vivos, isto é, esses sistemas não podem ser observados a não ser em suas observações, sua complexidade interna está vedada, como uma caixa preta $^{2}$, para o observador. Deste modo, a teoria dos sistemas de Luhmann está voltada para a realidade, mas concebe que a realidade de sua observação é uma construção interna à própria teoria e só é real enquanto tal, enquanto comunicação científica, não enquanto objeto.

\footnotetext{
${ }^{2}$ Modelo Black Box da Cibernética moderna.
} 
Algumas dessas implicações gerais e epistemológicas da sociologia de Luhmann serão abordadas na exposição, assim como o debate com Jürgen Habermas e as confluências e divergências com Émile Durkheim.

Palavras Chave: Teoria social, Autopoiesis, Comunicação, Consciência

\section{Referências}

LUHMANN, Niklas. “Introdução à Teoria dos Sistemas”. Editoras Vozes, 2009. “A realidade dos meios de comunicação". Editora Paulus, 2011. . "Sociedad y sistema: La ambisión de La teoria". Ediciones Paidós Ibérica, 1990.

MATURANA, Humberto e VARELA, Francisco. “A árvore do conhecimento - As bases biológicas do conhecimento humano". Editora Psy II, 1995.

PEIRCE, Charles Sanders. "Escritos coligidos”. Editora Abril, 1974.

SAUSSURE, Ferdinand. "Curso de Lingüística Geral”. Editora Cultrix, 2013. 